
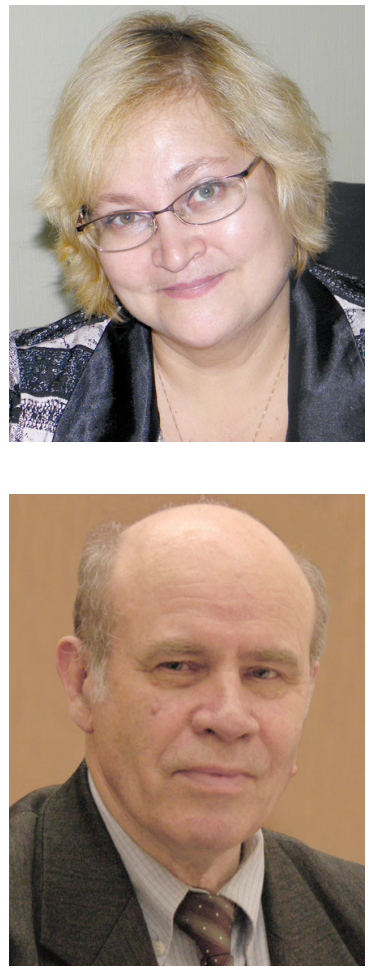

\section{Демина Ирина Николаевна}

доктор экономических наук, профессор, декан факультета журналистики, Байкальский государственный университет, 664003, Российская Федерация, г. Иркутск, ул. Ленина, 11, e-mail: demina-in@isea.ru

\section{Irina N. Demina}

Dr. in Economics, Professor, Dean of the Faculty of Journalism, Baikal State University, 11 Lenin St., Irkutsk, 664003, Russian Federation, e-mail: demina-in@isea.ru

\section{Шкондин Михаил Васильевич}

доктор филологических наук, профрессор, факультет журналистики, Московский государственный университет имени М. В. Ломоносова, 125009, Российская Федерация, г. Москва, ул. Моховая, 9, e-mail: skond@mail.ru

\section{Mikhail V. Shkondin}

Dr. in Philology, Professor, Faculty of Journalism, Lomonosov Moscow State University, 9 Mokhovaya St., Moscow, 125009, Russian Federation, e-mail: skond@mail.ru

\title{
ЖУРНАЛИСТИКА: СЛАГАЕМЫЕ ЦЕЛОСТНОСТИ
}

\footnotetext{
Аннотация. На основе анализа статей Г. В. Лазутиной, опубликованных в ее книге «Журналистика в жизни общества - пером теоретика и практика», исследуются основные аспекты целостности журналистики как системного объекта. Характеризуется острая необходимость расширения информационных возможностей человека в современном обществе как личности, нуждающейся в удовлетворении ее возрастающих потребностей в знаниевых, аксиологических и поведенческих ресурсах на основе освоения интеллектуального потенциала общества, а также как носителя тех ресурсов, которые нужны для постоянного обогащения, обновления информационного потенциала социума. Публичность социальной деятельности на современном цивилизационном этапе может быть достигнута только в условиях достижения ее целостности, непрерывного развития интегративных свойств журналистики как системного объекта: ее функциональности, структурности, коммуникативности, оптимальности информационного поля, медиакартины мира и организованности.

Ключевые слова. Публичность, инфосорера, целостность журналистики, информационное поле, медиакартина мира.

Информация о статье. Дата поступления 10 августа 2016 г.; дата принятия к печати 3 октября 2016 г.; дата онлайн-размещения 31 октября 2016 г.
} 


\title{
JOURNALISM: ELEMENTS OF INTEGRITY
}

\begin{abstract}
The main elements of integrity of journalism as a system object are studied in this article. The study is based on the analysis of the articles by G. V. Lazutina published in the book Journalism in the Life of Society from the Viewpoint of Theory and Practice (Zhurnalistika $v$ zhizni obschestva perom teoretika I praktika). The article describes the urgent necessity for broadening sources of information in modern society as people require to fill the need for knowledge, axiology and behaviorial resources. This need emerges from getting aware of mental performance of the society people live in. Within the research the man is also studied as already having the resources necessary for broadening and updating society information capacity. The publicity of social activity nowadays can be only achieved by ensuring its integrity, constant development of ingertative properties of journalism as a system object, its functionality, structural properties, communicativeness, information realm optimality, the media world building and good organization.

Keywords. Publicity, information realm, integrity of journalism, media world building.

Article info. Received August 10, 2016; accepted October 3, 2016; available online October 31, 2016.
\end{abstract}

Важным фрактором оптимизации системы социальной деятельности, направленной на освоение и преобразование мира, является инфоссре$\mathrm{pa}^{1}$, ее структурные составляющие, и прежде всего медиасорера, журналистика. В условиях научно-технической революции, становления со-

1 Понятие «инфоссрера» впервые официально введено в России Доктриной информационной безопасности, утвержденной указом президента РФ от 9 сентября 2000 г. Оно официально закреплено также в паспорте специальности 10.01.10 - журналистика. Инфосфера - сложная целостная система, вбирающая в себя медиасферу (медиасистему), а также другие сферы, основанные на информационном взаимодействии. Инфросфрера - это совокупность информации, информационных объектов, информационных процессов, информационной инфраструктуры. Она включает в себя и участников межличностного и массового общения, осуществляющих сбор, обработку, хранение, распространение, производство и потребление иноормации, а также субъектов регулирования возникающих при этом отношений производства, использования, владения и распоряжения информацией (см.: [1]). временного этапа цивилизационного развития существенно преобразуется сорера социального взаимодействия, что вызывает необходимость системного исследования как инфосореры в целом, так и ее различных субъектов, в том числе и журналистики.

Выступая с докладом на открытии международной научно-практической конференции, декан фракультета журналистики МГУ имени М. В. Ломоносова Е. Л. Вартанова назвала насущную необходимость, которую должна реализовать современная журналистика, действующая в условиях интеллектуализации и инноватизации общества. Это необходимость в расширении информационных возможностей современного человека, всех субъектов социальной деятельности ${ }^{2}$. Задача состоит не только в том, чтобы расширить объем информационных ресурсов личности,

2 Журналистика в 2015 году. Информационный потенциал общества и ресурсы медиасистемы. Москва, 5-6 февр. 2016 г. М. : Фак. журналистики МГУ им. М. В. Ломоносова. 
различных социальных общностей, которые действуют в новых условиях преобразования действительности. Необходимо через массовый информационный процесс расширить возможность личности, различных социальных общностей и структур активизировать свое участие в процессах освоения и преобразования мира на основе интеллектуализации их социальной деятельности как деятельности коллективной, сознательной, организованной в рамках субъективного фрактора цивилизационного развития. Важно, чтобы информационные потоки базировались на инновационной основе, на интеллектуальном потенциале общества, на новейших достижениях в материальном и духовном производстве, которые рождает современный этап социального прогресса.

В этой связи перед теорией журналистики стоит задача более глубокого изучения фундаментальных основ медиалогии, в том числе проблем целостности журналистики, того единого интегративного результата ее функционирования как системного объекта, на достижение которого направлено функционирование всех ее частей. Этот результат наполняет журналистику такими интегративными свойствами, без которых ей невозможно выполнять свою миссию в процессах стремительной интеллектуализации всех сорер социальной деятельности.

В последние годы заметный вклад в изучение целостности журналистики внесли многие отечественные ученые, в том числе Е. Л. Вартанова, Д. П. Гавра, В. М. Горохов, Я. Н. Засурский, В. П. Коломиец, С. Г. Корконосенко, Б. Н. Лозовский, В. Д. Мансурова, Б. Я. Мисонжников, В. Ф. Олешко, Л. Г. Свитич, А. А. Тертычный, В. В. Тулупов и др. [2-14]. Эти проблемы исследу- ются также в книге Г. В. Лазутиной, вышедшей в 2016 г. на факультете журналистики МГУ [15]. Уже появились первые рецензии на данную работу в научных изданиях (СМ., например, [16]). Наша цель состоит в том, чтобы рассмотреть лишь некоторые аспекты этой книги, связанные с анализом в ней характера целостности современной журналистики, которая претерпевает значительную трансформацию.

Вначале несколько слов о методологии системного исследования проблем целостности журналистики, которую использует автор рецензируемой работы.

Можно считать устоявшимся суждение о том, что целостность является главным свойством любой системы. Целостность характеризует единство журналистики как системного объекта, ее единый интегративный результат, достигаемый посредством взаимодействия компонентов системы. В процессе этого взаимодействия возникают новые интегративные качества, которыми элементы системы не располагают (эмерджентность) - интегративные свойства системы.

Наличие интегративных свойств является одной из важнейших черт системы. Целостность проявляется в том, что система обладает собственными закономерностями и механизмами их реализации.

Интегративные результаты взаимодействия между ее компонентами, между нею и средой рождают важные интегративные качества. В их числе функциональность как проявление определенных свойств (функций) при взаимодействии с внешней средой. С функциональностью связано формирование цели (назначения системы) как желаемого конечного результата. Свойством системы является также структур- 
ность как строение системы, способ связи ее компонентов, образование различных структурных множеств, диффреренцирующих и объединяющих компоненты между собой. Важным свойством систем является их организованность - сложное свойство, обеспечивающее оптимальность структуры и оптимальное функционирование (поведение) в соответствии с имеющимися закономерностями и функциями. Считается, что это поведение системы связано со средой (окружающей), т. е. с другими системами с которыми она входит в контакт или вступает в определенные взаимоотношения. Система состоит из компонентов, взаимодействующих между собой. Целостность системы означает, что каждый ее компонент вносит свой вклад в реализацию единой целевой функции системы [17].

Опираясь на системный подход, Г. В. Лазутина видит целостность журналистики в рамках более общего системного образования социальной деятельности общества [15, с. 59-60]. Такой подход становится доминирующим в целом ряде отечественных исследований. Так, в книге коллектива авторов, вышедшей под редакцией Е. Л. Вартановой, «Журналистика как система средств массовой информации» отмечается, что сущность журналистики в том, что она представляет собой особую сферу в системе социальной деятельности [18]. С. Г. Корконосенко рассматривает журналистику как род деятельности [7]. Б. Я. Мисонжников исследует журналистику в системе способов отражения мира [11].

В современный период происходят существенные преобразования характера целостности медиасистемы, и исследование этих процессов - важный этап развития теории журналистики. В центр внимания исследователей все активнее начинают входить проблемы существенного обогащения информационного потенциала общества' на базе всеобъемлющего включения в этот процесс интеллектуального, инновационного потенциала ${ }^{2}$, рожденного в срерах материального и духовного производства, освоения его всеми социальными субъектами, входящими в структуру субъективного фрактора цивилизационного развития.

Вместе с тем в российском обществе наблюдается острое противоречие между интеллектуальным потенциалом социума и его исполь-

1 Информационный потенциал общества - это накопленный в нем информационный ресурс, постоянно создаваемый и обогащаемый как субъектами духовного производства, так и участниками других видов социальной деятельности, и представляющий собой концентрированное выражение научных знаний и практического опыта для накопления знаниевых, ценностно-ориентационных, проективно-поведенческих ресурсов. IT-технологии. URL : http://www. irkinfo.ru/informatsionnyipotentsialobshchestva.html; URL : http: / /21 next.capital.ru/TforR.

2 Интеллектуальный потенциал - комплексная характеристика уровня развития интеллектуальных, творческих возможностей, ресурсов страны, отрасли, личности. К его изучению можно подходить с двух сторон: как к совокупности людей - обладателей знания, ориентирующихся на познавательную и преобразовательную деятельность; как к совокупности научных, технических, социальных, культурных знаний, овеществленных в материально-технических формах и знаковых системах, являющихся средством достижения целей общества. Интеллектуальный потенциал определяется уровнем развития данного общества, системы образования и просвещения, науки, культуры, генетическим фондом общества. Интеллектуальный потенциал характеризуется интеллектуальной деятельностью общества. URL : http: / / old. problemanalysis.ru/konf1/belyaeva.pdf. 
зованием в практике освоения и преобразования действительности. Это противоречие состоит в том, что многие знаниевые, аксиологические, поведенческие ресурсы, рождающие новые возможности освоения и преобразования действительности, не становятся достоянием личности, различных социальных общностей, действующих в системе общественного разделения труда. Таким образом, информационные потребности членов общества, вызванные нехваткой креативной иноормации, удовлетворяются лишь частично. Значительная часть интеллектуального потенциала общества превращается в неиспользованный информационный ресурс.

Г. В. Лазутина считает, что в современных условия существует противоречие между назначением журналистики и реальным фрункционированием медиа. Изучение этого противоречия встало в повестку дня именно в сегодняшних условиях, когда стали отчетливо проявляться дисфункциональные эфффекты деятельности отечественных СМИ. Это противоречие, полагает автор, может быть связано с рассогласованием позиций по отношению к месту и роли журналистики в обществе тех, кто причастен к фрункционированию массмедиа. [15, с. 146-147].

Ослабление этих противоречий, их устранение во многом зависит от успехов в анализе теоретических основ журналистики, и прежде всего в исследовании характера ее целостности как системного объекта.

В книге Г. В. Лазутиной отмечается, что целостность как интегративный результат, дающий новые свойства журналистике как системному объекту, носит многоаспектный характер. В ее работе дается характеристика многих важных аспектов этой целостности.
Автором в его работе исследуется функциональная целостность журналистики, ориентирующая участников медийных действий на формирование единых для них всех интегративных результатов. Необходима такая совокупность ффункций и такая степень их актуализации, когда обеспечивается реализация публичности социальной деятельности. Эта публичность достигается благодаря созданию различных интегративных качеств. В основе функциональной целостности - интегративная ффункция журналистики, ее миссия, назначение $[15$, с. 101$]$.

Именно здесь определяется, каким должен быть интегративный результат функционирования журналистики как медиасистемы.

Его основу составляет, вопервых, познавательно-отражательная целостность: это и оптимальное информационное поле, вбирающее в себя информационный потенциал общества, материализуемый в медиаконтенте. Именно на основе регулярно обновляемого и обогащаемого информационного потенциала общества рождается медиакартина мира в сознании личности, различных социальных общностей, в общественном сознании в целом $[15$, с. 33-35, 46]. Оно обновляется на основе сепарации «культурного слоя» общественной жизни, сложившегося в обществе в данный момент. Этот потенциал непрерывно обновляется на основе результатов социальной деятельности [Там же, с. 15-21], адекватными отображениями реалий [Там же, с. 71-80], несущими инновации, объемную полифоническую картину действительности [Там же, с. 80-84]. Создается медиакартина мира в сознании массовой аудитории, вбирающая в себя важнейшие знаниевые, аксиологические и поведенческие ресурсы общества, 
удовлетворяющие информационные потребности субъектов социальной деятельности, в том числе личности, различных социальных общностей и организаций, общества в целом; Она призвана нести медиаобраз Земли, медиаобраз России, движущуюся информационную картину современности [Там же, с. 53-54, 84].

Структурная целостность, обеспечивающая реализацию этих функций, образует разнообразные способы связи компонентов медиасистемы, Оптимальное строение системы создает механизмы активизации их потенциальных свойств, формирует в различных социальных пространствах общества медийные пространства, в которых осуществляется информационное взаимодействие различных субъектов социальной деятельности.

Большое внимание уделяет Г. В. Лазутина такому понятию, как коммуникативная целостность, формирующая и развивающая систему информационных отношений между участниками массового информационного процесса; обеспечивающая создание арены свободного обмена мнениями, диалога, сотрудничество представителей самых различных видов информационного производства [15, с. 83]. Коммуникативная целостность состоит в создании оптимального медиапространства, обеспечивающего непрерывное взаимодействие между всеми субъектами социальной деятельности. Именно инорормационное взаимодействие, налаженное посредством медиа между различными социальными субъектами, и есть важнейший коммуникативный аспект целостности журналистики. По сути своей это хорошо налаженное информационное взаимодействие посредством массовой информации между различными способами освоения мира, в том числе теоретическим, художественным, практическим и другими.

\section{Организационная целостность} состоит в том, что журналистика становится организатором всей медиасферы, что она является организатором массового информационного процесса. Это состояние организованности медиасистемы, ее структурных и фрункциональных элементов. Это и сам организационный процесс, включающий в себя все основные составляющие управленческого цикла: исследовательские функции управления, принятие решений, их реализация, учет и контроль за их выполнением. Это также совокупность организаций (редакций, других организационных структур, фрорм сотрудничества разных общественных сил [15 с. 72-73]. Организованность рассматривается как состояние системы, как процесс ее организации и как совокупность различных организаций

Целостность журналистики как системного объекта состоит в том, что она, как отмечалось выше, обеспечивает реализацию целевой функции системы. Функция, по мнению М. И. Сетрова, это отношение части к целому, при котором само существование или форма проявления части обеспечивает существование или какую-либо форму проявления целого ${ }^{1}$. Если цельм является социальная деятельность, а журналистика - частью этого целого, то формой проявления этого целого являются интегративные результаты этой деятельности, фоомирующие публичность социальной деятельности в целом, различных ее видов и самих социальных субъектов, в ней участвующих: личности, социальных общностей, организаций [19; 20].

\footnotetext{
${ }^{1}$ URL : http://www.cih.ru/ab/b39/html.
} 
Целостность журналистики также в том, что она создает для всех участников процессов освоения и преобразования мира отношения публичности, обеспечивающие формирование в сознании массовой аудитории, еe различных субъектов (личности, социальной общности) такой инорормационный потенциал (знаниевый, аксиологический, проективно-поведенческий), который обеспечивает удовлетворение их информационных потребностей. Формируемые при этом информационные отношения становятся средством постоянного обновления информационного потенциала общества на основе широкого использования его интеллектуального, инновационного потенциала'.

Массовые коммуникации в условиях современного цивилизационного этапа обретают новую качественную определенность. Они становятся более востребованными у широкого круга создателей инновационных духовных продуктов, которые необходимы участникам процессов освоения и преобразования мира. Расширяющиеся возможности интеллектуального, технологического, экономического, организационного потенциалов общества требуют их продуктивного использования в массовой информационной деятельности для удовлетворения возросших

1 Инновационный потенциал характеризует готовность экономики и общества в целом, как к технологическим, так и социальным изменениям. Он относится в любом государстве к категории национального достояния, а в ряде стран существует законодательство, охраняющее его. Инновационный потенциал представляет собой совокупность различных видов ресурсов, включая материально-производственные, финансовые, интеллектуальные, научнотехнические и иные ресурсы, необходимые для осуществления инновационной деятельности. URL : http: / / eclib.net/44/13.html. потребностей массовой аудитории, включающей различные структуры субъективного фактора социального прогресса. Характер публичности современной инфосферы, медиасферы состоит в том, чтобы активно вовлекать в массовый информационный процесс широкий круг носителей интеллектуального потенциала общества, его инновационных достижений, обеспечивая тем самым обогащение, обновление информационного потенциала общества, вбирающего в себя креативные медиаресурсы. И на этой основе, взаимодействуя с массовой аудиторией, активно приобщать ее к освоению этого потенциала, к созданию в сознании личности, различных социальных общностей медиакартины мира, способствующей тем самым их активному участию в социальных преобразованиях.

Системы публичности и инновационности неразрывно связаны друг с другом. Публичность - одно из центральных понятий теории журналистики. Она характеризует состояние информационных отношений в системе общественного разделения труда, создаваемых инфосфрерой, в том числе ее важной составляющей - медиасферой. Личность, различные социальные общности, организации, выступающие как субъекты массового информационного процесса, в условиях публичности должны иметь возможность быть публичными субъектами. Имеется в виду такой уровень их участия в массовом информационном процессе, который обеспечивает удовлетворение их потребностей при освоении информационного потенциала общества. Другой стороной этого процесса является открытость данного субъекта перед общественностью как участника тех или иных видов совместной социальной деятельности. 
Речь идет также о доступности ему различных медиа как автора или источника массовой информации.

Личность, группа, организация, выступающие как субъекты массового информационного процесса, в условиях публичности имеют возможность полноценно участвовать как в создании информационного потенциала общества, его обогащении, обновлении, так и в его освоении, удовлетворяя в полной мере свои потребности в массовой информации. Публичность возникает тогда, когда научный потенциал общества как результат теоретического освоения мира становится важнейшей составной частью информационного потенциала и доступен участникам других видов социальной деятельности. То же самое можно сказать об искусстве, сорере образования, производства, управления и др. [15].

Таким образом, публичность возникает:

- когда условия жизнедеятельности общества на уровне единичного, особенного и всеобщего объективно отражаются в информационном потенциале общества и непрерывно обновляют медиакартину мира в сознании массовой аудитории адекватно этим условиям;

- когда достижения интеллектуального потенциала общества постоянно обновляют, обогащают его инорормационный потенциал;

- когда медиакартина мира в сознании личности, различных социальных общностей создается на основе удовлетворения их информационных потребностей, связанных с участием в процессах освоения и преобразования мира;

- когда сама личность, различные социальные общности, организации открыты для сообщества всеми сторонами своей социальной деятельности
Публичность инфосферы реализуется через процессы непрерывного воссоздания и освоения информационного потенциала общества. На основе взаимодействия различных социальных субъектов, участвующих в различных видах материального и духовного производства, оптимизируются инорормационные отношения между ними. Но публичность их деятельности может возникнуть только при таком уровне этих отношений, когда каждый из них станет в полной мере удовлетворять свои потребности как в освоении информационного потенциала общества, так и в его обновлении, обогащении результатами своей деятельности.

Оптимальные информационные отношения, именуемые публичностью, необходимы не только для того, чтобы усилиями взаимодействующих между собой сфер духовного, духовно-практического и практического характера непрерывно воссоздавать, обновлять, обогащать информационный потенциал общества, но и для того, чтобы осваивать его, отражать в сознании (индивидуальном и массовом, групповом) медиакартину мира, знаниевые, аксиологические и проективно-поведенческие ресурсы, необходимые для совместной практической деятельности. При этом оптимальные информационные отношения на базе оптимального информационного потенциала общества способствуют оптимизации различных общественных отношений, в том числе отношений координации, субординации, инициативы, дисциплины, ответственности и др.

Основные системные качества публичности состоят в следующем:

- обеспечивается адекватность процесса обновления, обогащения информационного потенциала общества процессу обогащения, об- 
новления его интеллектуального потенциала;

- инновационность информационного потенциала общества должна в полной мере вбирать в себя инновационные результаты всех видов социальной деятельности в системе общественного разделения труда;

- информационный потенциал общества должен быть доступен каждому социальному субъекту: личности, социальной общности, организации, чтобы участвовать как в его освоении, так и обогащении результатами своей деятельности [15].

В массовом информационном процессе, обновляющем и осваивающем информационный потенциал общества, участвуют все творчески активные силы общества, составляющие ядро субъективного фактора цивилизационного развития. Это огромная совокупность субъектов коллективной массовой информационной деятельности, участвующих в производстве массовой информации и ее потреблении, освоении:

- представители науки, осуществляющие теоретическое освоение действительности;

- представители искусства, ведущие художественное освоение мира;

- представители образования, распространяющие научные знания, художественные и иные ценности в обществе;

- представители сореры управления, властных и правовых структур, обеспечивающих публичность политики, права, структур законодательной, исполнительной, судебной властей, других элементов системы организации и управления;

- представители гражданского общества, различных партий, движений, профессиональных, молодежных, других общественных организаций, участники производ- ственно-практической деятельности, выражающие общественное мнение и настроение, выступающие с предложениями и критикой;

- представители рекламной и $P R$-деятельности, обеспечивающие публичность структур различных видов социальной деятельности и управления [15, с. 43].

Автор отмечает, что участие в обновлении информационного поля медиа принимают представители всех сорер социальной деятельности, участвующих в духовно-теоретическом, художественном, практическом и других способах освоения мира.

Обогащение и обновление информационного поля основывается на результатах различных видов социальной деятельности: духовно-теоретической, эстетической, экономической, политической и иных. Это информационное поле представляет собой систему потенциальной инорормации, которой располагает общество, и которая материализуется в медиаконтенте различных средств массовой информации. Это информационное поле включает в себя те ресурсы, которые актуальны для личности как носителя различных групповых и общественных отношений, различных социальных групп и организаций. Это поле представляет собой интегративный результат, который:

- вбирает в себя результаты освоения и преобразования мира обществом адекватного непрерывной изменчивости в актуальных явлениях действительности;

- содержит, обогащает, обновляет информационные ресурсы, интеллектуальные результаты различных способов освоения и преобразования мира теоретического, художественного, практического и др.

Таким образом, Г. В. Лазутина видит интегративный результат в том, 
что журналистика на основе создания, регулирования массовых информационных потоков фоормирует медиакартину мира в сознании массовой аудитории, удовлетворяя ее потребности в необходимой информации для участия в коллективных процессах освоения и преобразования мира в системе общественного разделения труда. Эта медиакартина включает в себя знаниевые, аксиологические и поведенческие ресурсы и обеспечивает информационное взаимодействие в групповых и межгрупповых процессах освоения и преобразования условий жизни общества, опосредованных медийными средствами, взаимодействие в процессе преобразования действительности в рамках субъективного фрактора общественного прогресса,

На основании исследований Г. В. Лазутиной можно сделать вывод о том, что в рамках медиакартины мира мы имеем сложное структурное образование. Оно включает в себя множество различных картин с учетом существования различных социальных пространств, в которых действуют медиа. Это и медиакартина, общая для всего социума. И специализированная по формам, видам, уровням общественного сознания и сознания различных социальных общностей, имеющих многообразные виды деятельности.

По мнению исследователя, этот результат имеет сложную структуру, так как является результатом реализации интегративно-целевой функции журналистики (соотношение понятия цели, средства, результата). Это и картина текущей действительности - результат функционирования журналистики как разновидности духовного творчества, опирающегося на изменчивость в социальной деятельности и ее среде. носит как креативный, так и организационно- редакционный характер. В первом случае журналистика как творческая профессиональная деятельность создает медиакартину текущей действительности, постоянно корректируя, обогащая и дополняя ее новыми информационными ресурсами, связанными с происходящими каждодневно в обществе актуальными изменениями. В этом ей помогают представители различных сорер социальной деятельности, создавая различные публицистические материалы. Однако автор не согласен с теми исследователями, которые считают, что с развитием социальных сетей профессиональная журналистика как творческая деятельность исчезнет.

Нужна целостная картина текущей действительности, отражающая как изменчивость в условиях жизни общества, так и устойчивые процессы общественного развития. В массовом информационном процессе должны быть представлены все уровни освоения мира, в том числе теоретический и художественный. Поэтому в инорормационном поле, создаваемом в рамках масс-медиа, должна быть широко представлена научная, художественная и другая информация. Как организатор массового информационного процесса журналистика осуществляет сотрудничество с представителями всех сфер социальной деятельности, чтобы обеспечить публичность субъектов этой деятельности, обеспечить реализацию их коммуникативных функций. Журналистика, входящая в систему социальной деятельности, вносит значительный вклад в процессы массового взаимодействия между сорерами духовно-теоретической, духовно-практической и практической деятельности.

Г. В. Лазутина в своей работе обращает внимание на коммуникативный аспект целостности журна- 
листики. Она способствует взаимодействию:

- между теорией и практикой, наукой и производством, политикой и экономикой;

- между сознанием личности, различных социальных общностей и общественным сознанием;

- между теоретическим, духовно-практическим и практическим сознанием;

- между идеологией и общественной психологией;

- между различными состояниями сознания: мировоззрением, общественным мнением, общественным настроением и др.

- между различными формами общественного сознания: правового, политического, экономического и др. [15].

Общая тема целостности медиасистемы была бы неполной без еще одного аспекта, на который обращает внимание Г. В. Лазутина - проблемы аксиологии журналистики. В свое время был публикован сборник научных статей, полностью посвященный этим проблемам [21]. В рецензируемую книгу попала только одна из статей автора - «Печатные издания в процессе ценностного ориентирования аудитории: возможности и результаты». На самом деле проблемы аксиологии и связанные с ними проблемы деонтологии СМИ являются, пожалуй, системообразующими в сложнейшей медиасистеме, определяют ее структуру и функции. Одной из важнейших сорер человеческой деятельности является сфера экономической жизни, а результат этой деятельности часто определяется успешной функциональной комму- никацией (экономическая массовая коммуникация - ЭМК).

Картина мира, создаваемая медиасистемой (а именно, подсистемой ЭМК), определяет, в конечном итоге, экономическую эффрективность глобальной, страновой, региональной экономики и экономическое благополучие (или неблагополучие, если речь идет о дисфункциях в противоположность функциям) «человека с улицы». Это связано с изменениями экономического поведения, которые, в свою очередь, могут быть вызваны ценностными установками журналистов и системой ценностей, актуальной в системе СМИ. Участие в упомянутом сборнике даже заставило одного из авторов данной рецензии написать несколько статей, посвященных этим вопросам [22-25]. Вывод: без первоначального ориентирования в базовых ценностях, в культуре невозможно достичь эфффективного выполнения функций журналистики, необходимой для ориентирования в экономической жизни публичности, адекватной картины мира.

В книге Г. В. Лазутиной отражается широкий круг проблем теории и практики журналистики. Важным достоинством работы является их анализ с позиций системного, синергетического подходов. В условиях постиндустриального этапа развития общества, научно-технической революции преобразуются духовное и материальное производство, и медиасфрере, журналистике предстоит существенно обновить свою научную парадигму, сверить ее с велениями времени. Уверенные шаги на этом пути делает автор исследуемой книги.

\section{СПИСОК ИСПОЛЬЗОВАННОЙ ЛИТЕРАТУРЫ}

1. Соловьев И. В. О происхождении и содержании понятия «инфосфера». Инфосфера как объект исследования наукой об информации / И. В. Соловьев // Фундаментальные исследования. - 2013. - № 6-1. - С. 66-71. 
2. Вартанова Е. Л. Постсоветские трансформации российских СМИ и журналистики / Е. Л. Вартанова. - М. : МедиаМир, 2013. - 278 с.

3. Гавра Д. П. Основы теории коммуникации / Д. П. Гавра. - СПб. : Питер, 2011. - 285 с.

4. Горохов В. М. Интегрированные социальные коммуникации в журналистике / В. М. Горохов, М. Г. Шилина // Меди@льманах. - 2014. — № 3. - С. 12-27.

5. Засурский Я. Н. Коммуникация в обществе знаний / Я. Н. Засурский. - М. : МедиаМир, 2013. - 296 с.

6. Коломиец В. П. Медиасоциология: теория и практика / В. П. Коломиец. - М. : НИПКЦ Восход-А, 2014. - 328 с.

7. Корконосенко С. Г. Теория журналистики: моделирование и применение / С. Г. Корконосенко. - М. : Логос, 2010. - 242 с.

8. Лозовский Б. Н. Манипулятивные технологии управления средствами массовой информации / Б. Н. Лозовский. - Екатеринбург : Изд-во Урал, ун-та, 2008. - 217 с.

9. Олешко В. Ф. Журналистика как творчество / В. Ф. Олешко. - М. : РИП-Холдинг, 2005. -222 c.

10. Мансурова В. Д. Журналистская картина мира как фактор социальной детерминации / В. Д. Мансурова. - Барнаул : Изд-во Алт. гос. ун-та, 2002. - 237 с.

11. Мисонжников Б. Я. Отражение действительности в тексте / Б. Я. Мисонжников // Основы творческой деятельности журналиста / под ред. С. Г. Корконосенко. - СПб. : Знание, 2000. - 272 с.

12. Свитич Л. Г. Феномен журнализма / Л. Г. Свитич. - М. : Фак. журналистики МГУ, 2000. -252 c.

13. Тертычный А. А. О понятийной основе современной теории журналистики / А. А. Тертычный // Научные ведомости Белгородского государственного университета. Серия Гуманитарные науки. - 2014. - № 6 (161). - С. 290-295.

14. Тулупов В. В. Конвенциональная коммуникационная стратегия в журналистской деятельности / В. В. Тулупов // Вестник Московского университета. Сер. 10, Журналистика. - 2009. - № 5. - С. 20-49.

15. Лазутина Г. В. Журналистика в жизни общества - пером теоретика и практика / Г. В. Лазутина. - М. : Фак. журналистики МГУ, 2016. - 252 с.

16. Панкеев И. В защиту профессии / И. Панкеев // МедиаАльманах. - 2016. № 2. - С. $130-132$.

17. Родионов И. Б. Теория систем и системный анализ [Электронный ресурс] / И. Б. Родионов. - Режим доступа : victor-safronov.ru/systems-analysis/lectures/rodionov $/ 01 / \mathrm{html}$.

18. Журналистика как система средств массовой информации [Электронный ресурс] / Е. Л. Вартанова, Засурский Я. Н. [и др.]. - Режим доступа // http://sci.house/smijurnalistika/jurnalistika-kak-sistema-sredstv-massovoy-40582.html.

19. Luhmann Niklas. Die Realitat der Massenmtdien / Niklas Luhmann. - Wiesbaden, Westdeutscher Verlag, 2004. - $256 \mathrm{~s}$.

20. Habermas J. The Structural Transformation of the Public Sphere: An Inquiry into a category of Bourgeois Society / J. Habermas. - Cambridge : MIT Press, 1962. - 301 p.

21. Массмедиа и ценностные отношения общества : сб. науч. ст. / под ред. Г. В. Лазутиной. - М. : МедиаМир, 2013. - 320 с

22. Демина И. Н. Экономическая коммуникация. обоснование термина / И. Н. Демина // Известия Иркутской государственной экономической академии. - 2012. № 1 (81). - С. 162-166.

23. Демина И. Н Методологические подходы к исследованиям роли экономических массовых коммуникаций в формировании экономического поведения [Электронный ресурс] / И. Н. Демина // Меди@льманах. - 2012. - Вып. 4. - Режим доступа : http: // www.mediascope.ru/node/1222.

24. Демина И. Н. Предметные ценности в системе экономической массовой коммуникации / И. Н. Демина // Известия Иркутской государственной экономической академии. - 2012. - № 6 (86). - С. 144-149.

25. Демина И. Н. Методологические подходы к ценностям: основания экономической массовой коммуникации / И. Н. Демина / / Вопросы теории и практики журналистики. 2012. — № 2. - С. 32-49. 


\section{REFERENCES}

1. Solov'ev I. V. On the origin and content of the concept infosphere. Infosphere as object of research of information science. Fundamental'nye issledovaniya = Fundamental Investigations, 2013, no. 6-1, pp. 66-71. (In Russian).

2. Vartanova E. L. Postsovetskie transformatsii rossiiskikh SMl i zhurnalistiki [The post-Sovief Transformation of the Russian Media and Journalism]. Moscow, MediaMir Publ., 2013. 278 p.

3. Gavra D. P. Osnovy teorii kommunikatsii [Basic Theory of Communication]. Saint Petersburg, Piter Publ., 2011. $285 \mathrm{p}$.

4. Gorokhov V. M., Shilina M. G. Integrated social communications in journalism. Medi@/manah, 2014, no. 3, pp. 12-27. (In Russian).

5. Zasurskii Ya. N. Kommunikatsiya $v$ obshchestve znanii [Communication in the Knowledge Society]. Moscow, MediaMir Publ., 2013. 296 p.

6. Kolomiets V. P. Mediasotsiologiya: teoriya i praktika [Media Sociology: Theory and Practice]. Moscow, NIPKTs Voskhod-A Publ., 2014. 328 p.

7. Korkonosenko S. G. Teoriya zhurnalistika: modelirovanie i primenenie [The Theory of Journalism: Modeling and Application]. Moscow, Logos Publ., 2010. 242 p.

8. Lozovskii B. N. Manipulyativnye tekhnologii upravleniya sredstvami massovoi informatsii [Manipulative Techniques Used to Contorl the Media]. Yekaterinburg, Ural University Publ., 2008. 217 p.

9. Oleshko V. F. Zhurnalistika kak tvorchestvo [Journalism as an Art]. Moscow, RIP-Kholding Publ., 2005. 222 p.

10. Mansurova V. D. Zhurnalistskaya kartina mira kak faktor sotsial'noi determinatsii [Journalistic Picture of the World as a Factor of Social Determination]. Barnaul, Altai State University Publ., 2002. 237 p.

11. Misonzhnikov B. Ya. Interpretation of Reality in Texts. In Korkonosenko S. G. (ed.). Osnovy tvorcheskoi deyatel'nosti zhurnalista [Fundamentals of Creative Activity of Journalists]. Saint Petersburg, Znanie Publ., 2000. 272 p. (In Russian).

12. Svitich L. G. Fenomen zhurnalizma [The Phenomenon of Journalism]. Moscow State University Publ., 2000. 252 p.

13. Tertychnyi A. A. On Conceptual Principles of Modern Theory of Journalism. Nauchnye vedomosti Belgorodskogo gosudarstvennogo universiteta. Seriya Gumanitarnye nauki $=$ Belgorod State University Scientific Bulletin Humanities Philology. Journalism. Pedagogy. Psychology, 2014, no. 6 (161), pp. 290-295. (In Russian).

14. Tulupov B. B. Conventional Communicative Strategy in Journalism. Vestnik Moskovskogo universiteta. Seriya 10. Zhurnalistika = Moscow University Bulletin. Journalism, 2009, no. 5, pp. 20-49. (In Russian).

15. Lazutina G. V. Zhurnalistika v zhizni obshchestva - perom teoretika i praktika [Journalism in the Life of Society from the Viewpoint of Theory and Practice]. Faculty of Journalism, Lomonosov Moscow State University Publ., 2016. 252 p.

16. Pankeev I. Protection of the Profession. Medi@Imanah, 2016, no. 2, pp. 130-132. (In Russian).

17. Rodionov I. B. Teoriya sistem i sistemnyi analiz [Systems Theory and Systems Analysis]. Available at: victor-safronov.ru/systems-analysis/lectures/rodionov/01/html. (In Russian).

18. Vartanova E. L., Zasurskii Ya. N. et al. Zhurnalistika kak sistema sredstv massovoi informatsii [Journalism as the Media System]. Available at: http://sci.house/smi-jurnalistika/ jurnalistika-kak-sistema-sredstv-massovoy-40582.html. (In Russian).

19. Luhmann Niklas. Die Realitat der Massenmtdien. Wiesbaden, Westdeutscher Verlag, 2004. $256 \mathrm{~s}$.

20. Habermas J. The Structural Transformation of the Public Sphere: An Inquiry into a category of Bourgeois Society. Cambridge, MIT Press, 1962. 301 p.

21. Lazutina G. V. (ed.) Massmedia i tsennostnye otnosheniya obshchestva [Mass Media and The Society's Value Relationships]. Moscow, MediaMir Publ., 2013, 320 p.

22. Demina I. N. Economic communication. Substantiation of term. Izvestiya Irkutskoi gosudarstvennoi ekonomicheskoi akademii = Bulletin of Irkutsk State Economics Academy, 2012, no. 1 (81), pp. 162-166. (In Russian). 
23. Demina I. N. Methodological approaches to the research roles of economic mass communications in the formation of economic behaviour. Medi@Imanah, 2012, iss. 4. Available at: http: / / www.mediascope.ru/node/1222. (In Russian).

24. Demina I. N. Substantive values in the system of economic mass communication. Izvestiya Irkutskoi gosudarstvennoi ekonomicheskoi akademii = Bulletin of Irkutsk State Economics Academy, 2012, no. 6 (86), pp. 144-149. (In Russian).

25. Demina I. N. Methodological approaches to values: Graunds of economic mass communication. Voprosy teorii i practiki zhurnalistiki $=$ Theoretical and Practical Issues of Journalism, 2012, no. 2, pp. 32-49. (In Russian).

\section{БИБЛИОГРАФИЧЕСКОЕ ОПИСАНИЕ СТАТЬИ}

Демина И. Н. Журналистика: слагаемые целостности / И. Н. Демина, М. В. Шкондин / / Вопросы теории и практики журналистики. - 2016. - Т. 5, № 4. - С. 562-575. DOI: $10.17150 / 2308-6203.2016 .5(4) .562-575$.

\section{REFERENCE TO ARTICLE}

Demina I. N., Shkondin M. V. Journalism: elements of integrity. Voprosy teorii i praktiki zhurnalistiki $=$ Theoretical and Practical Issues of Journalism, 2016, vol. 5, no. 4, pp. 562-575. DOI: 10.17150/2308-6203.2016.5(4).562-575. (In Russian). 